\title{
Assessment of Urban Governance Using UN-Habitat Urban Governance Index: A Case Study of Tehsil Municipal Administrations of Punjab, Pakistan
}

\author{
Rizwan Ur Rehman, Abdul Waheed", Malik Asghar Naeem \\ Department of Urban \& Regional Planning, School of Civil and Environmental Engineering, National University of Sciences and \\ Technology, Islamabad, Pakistan
}

\section{Email address:}

drwaheed@nit.nust.edu.pk (A. Waheed)

${ }^{*}$ Corresponding author

\section{To cite this article:}

Rizwan Ur Rehman, Abdul Waheed, Malik Asghar Naeem. Assessment of Urban Governance Using UN-Habitat Urban Governance Index: A Case Study of Tehsil Municipal Administrations of Punjab, Pakistan. Urban and Regional Planning. Vol. 2, No. 4, 2017 , pp. 17-24. doi: $10.11648 /$ j.urp.20170204.11

Received: May 16, 2017; Accepted: August 21, 2017; Published: September 11, 2017

\begin{abstract}
UN HABITAT in 1999 launched "Global Campaign on Urban Governance" in order to support the implementation of the Habitat agenda goal of "sustainable human settlements development in an urbanizing world". Under this campaign Urban Governance Index (UGI) was developed in 2004 to assess the level of governance at global and local level. The research has been undertaken to evaluate the existing situation of urban governance in local governments particularly Tehsil Municipal Administrations (TMAs) in Punjab, Pakistan using the urban governance index. Data was collected through structured interviews, surveys and secondary sources regarding four sub-indexes of UGI comprising Effectivity, Equity, Participation and Accountability involving total 26 number of indicators. The results revealed the average UGI of the TMAs in Punjab as 0.40 on a scale of 0 to 1 which transpires quite poor condition of urban governance in Pakistan. The detailed results depicted the average Effectiveness and Equity sub index values as 0.32 and 0.31 respectively. A meagre value was recorded in case of Participation sub index as 0.02 which was primarily due to the absence of elected local governments. The Accountability Sub Index secured highest value and was recorded as 0.97 which shows strong prevalence of accountability in the TMAs. The highest UGI value was observed in cities of Attock and Murree in Northern Punjab which was calculated as 0.45. When Compared with UGI of 24 different cities of developing world, these cities stand at $22^{\text {nd }}$ position which shows quite poor situation with regard to the urban governance. Research has also highlighted some key urban governance issues across TMAs of Punjab such as low revenue generation, absence of elected local government, lack of public and women participation and poor service delivery.
\end{abstract}

Keywords: UN Habitant Governance Index, Urban Governance, Urban Governance Index

\section{Introduction}

World is witnessing huge urbanization since the beginning of $20^{\text {th }}$ century. In $1950,30 \%$ of world population was residing in urban areas which increased to $54 \%$ by 2014 . The prevailing population growth and urbanization trends will add 2.5 billion people to the world urban population by 2050 which according to the estimates shall be $66 \%$ of the world population [1]. Urbanization besides having some advatages such as economic development, social and cultural integration, comparative advantage of cities, high income levels, more productivity and richer market structures also posses very serious threats to cities such as overburdened infrastructures, shifitng of rural poverty to urban poverty, slums formation and environmental degradation [2]. Besides, development agencies in large cities are often confronted by a lot of challenges like large urban densities, transport, traffic congestion, energy inadequacy, unplanned development and lack of basic services, illegal construction both within the city and in the fringe, informal real estate markets, poor natural hazards management in overpopulated areas, crime, water, soil and air pollution leading to environmental degradation, climate change and poor governance arrangements [3]. Although, various efforts have been made 
by city administrations across the world to overcome these problems by using wide range of tools for planning, infrastructure, development and land use controls, transportation, environmental management and water management etc., yet, over the time it has been realized that the key solution to these problems lies in better governance [4].

Study of Urban Governance has gained much importance during the recent past. Launching of the "Campaign on Urban Governance" by the UN HABITAT in 1999 [5] and the formulation of Urban Governance Index shows the importance of Urban Governance towards eradication of poverty in the urban areas and fullfillement of Habitat Agenda goal of "sustainable human settlements development in an urbanizing world". This study may assist cities to relate progress among each other and to accelerate the change at the local level by supporting city managers and politicians with thoughts as how they can improve the GI value in their cities. The study may also help in identifying the areas lacking good management and in enhancing the efficiency for delivery of services. Furthermore, this type of study has not been conducted in Pakisan ever before and hence may act as first spoon in measuring urban governance.

The study primarily measures the level of urban governance in Tehsil/Town Municipal Administrations in Punjab (second tier of local government) using UNHABITAT Urban Governance Index. For this purpose, these TMAs are ranked on the basis of effectiveness, accountability, equity and community participation. The Local Government \& Community Development Department, which acts as watchdog on TMAs' functioning, may establish performance and reward system for more effective governance by expanding the sphere of exercise all over the country.

\section{Approaches to Measure Urban Governance}

Different approaches are being used by International agencies to define urban governance depending upon specific purpose [6]. In addition to this, these agencies translates the concept of governance into different approaches to measure the existing condition of urban governance and suggest actions to improve them [7]. For instance, Organization for Economic Cooperation and Development (OECD) has recognized that governance can be improved with efficient delivery of services by Government Sector. In addition, Transparency International has suggested that corruption is the indicator of good governance and has developed Corruption Perceptions Index (CPI) for this purpose. Moreover, Global Integrity, an international non profit organization that tracks governance around the world, has developed Global Integrity Index to assess the governance through existence of Governemnt rules and policies, and anti corrpution mechanism [8]. However, it is being observed that all these methods and tools lack the notion of "urban governance" and primarily focused on broader concepts of governance at international and institutional level. Stweart has suggested that this lack of work on "urban governance" assessment is perhaps due to the difficulties related to the data collection process [9]. He further pointed out that in order to overcome this issue two approaches are being evolved which include; World Bank database concerning globalisation, city governance and city performance [10] and UN-HABITAT Urban Governance Index [11].

World Bank database works on the hypothesis that weather globalization and good urban governance are helpful in improving the city performance [12]. The investigation performed by Daniel Kaufmann in 2004 suggests that "good governance and globalization (at both the country as well as at the city level) do matter for city-level performance in terms of access and quality of delivery of infrastructure services". He has also identified that a strong relation exist between city governance and globalization. The study covered 412 cities around the world and took 35 different variables and indicators into the account. The research suggests that "accessibility to services" being provided by the city is the key determinant of city governance. Furthermore indicators such as "well-functioning public sector with low bribery in taxes in the provision of utilities" were also taken into account. This is inline with the precise Bank database's objective that is to investigate empirically what determines the staying power of cities for their performance on a global scale, and whether governance has anything to do with it [10].

The other approach to measure the quality of Urban Governance is through urban governance index (UGI) using a set of 26 indicators. UN-HABITAT index demonstrates the importance of good urban governance in achieving broad development objectives, such as the Millennium Development Goals and those in the Habitat Agenda at the global level. Besides, the index also acts to catalyze local action to improve the quality of urban governance at the local level [11]. The Index has the overall purpose to make a contribution to the eradication of poverty, strengthening and improving urban governance. In contrast to the approach followed by World Bank, the selection of indicators in UGI is based upon the fundamental principle of inclusiveness covering four basic principles of effectiveness, equity, participation and accountability [13]. Therefore, the UGI specifically focuses on local governance both formal and informal irrespective of the globalization process as suggested by Kaufmann.

As it has already been presented in the Introduction part that the study aimed in measuring the governance level in local context in the selected case studies i.e all TMAs of Punjab and that it does not focus of how the cities are performing and delevering the services as a result of globalization. For this reason, the UN-HABITAT UGI has been chosen as the 'urban governance framework' of reference to measure the level of governance based upon the principles of effectiveness, equity, participation and accountability. However, the purpose of this study is not to 
evaluate the Urban Governance Index but to quantify the governance level in relation to various TMAs.

\section{The UN HABITAT Urban Governance Index}

In 1999, UN-HABITAT launched a "Global Campaign on Urban Governance" in order to support the implementation of the Habitat agenda goal of "sustainable human settlements development in an urbanizing world". The goal of this campaign was to contribute to the eradication of poverty through improved urban governance [5]. The ultimate aim of this campaign is "inclusiveness: cities where everyone regardless of wealth, gender, age, race or religion, is enabled to participate productivity and positively in the opportunities cities have to offer" [14]. The campaign proposed that equity, sustainability, subsidiarity, efficiency, transparency and accountability, civic engagement and security are the principles of sound urban governance. Under this campaign, Urban Governance Index was developed in 2004 by UNHABITAT after several meetings and extensive work by the researchers across the globe. This index is considered as an advocacy \& capacity building tool to assist city administrations and countries in monitoring their urban governance quality. The index primarily measures and quantifies the level of governance in cities based upon four major principles of governance i.e. Effectiveness, Equity, Accountability and Participation [15].

\section{Local Government System in Punjab}

At present, local government in Punjab is being governed by Punjab Local Government Ordinance 2001. This Local Government system is based on five basic rules and include Devolution of political power; Decentralization of administrative authority; De-concentration of management functions, Diffusion of the power - authority nexus and Distribution of sources [16]. Under this ordinance, three tiers of local government are established within Punjab each with distinct set of functions and responsibilities. These include District, Tehsil and Union Council [17]. In order to make the people actively participate at grass root level, village and neighborhood councils were established (Figure 1).

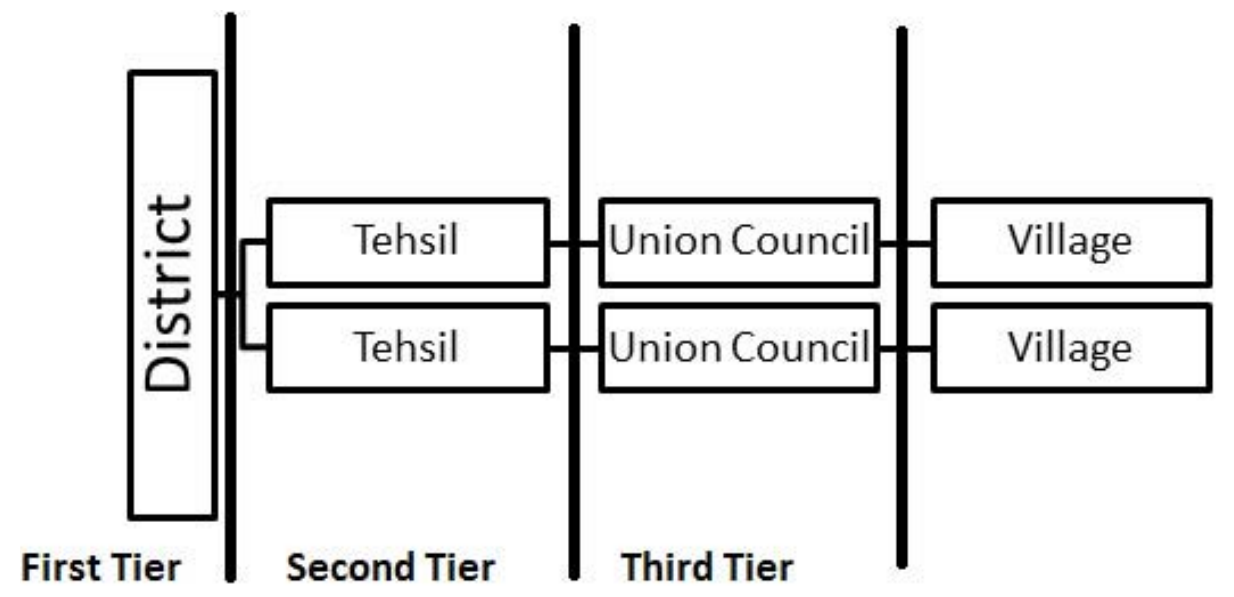

Figure 1. Local Government Structure in Punjab, Pakistan.

At the moment there are 36 districts, 144 Tehsil/Town Municipal Administrations and 3,454 Union Councils are working across Punjab [18]. District Governments are headed by the elected District/Zila Nazims. Under him different offices are working. The Tehsil/Town Nazim and Union Council Nazim are also elected at second and third tier respectively.

A district comprises of both urban and rural area hence it is in-appropriate to measure the urban governance at the district level. Similarly union council is the lowest tier and some cities are comprising more than 200 union council. Furthermore, functions of union council are very localized at neighborhood level and are limited to registration of births and deaths and other social aspects hence cannot be taken as framework to measure urban governance. On the contrary, majority of the municipal functions such as urban water supplies, solid waste management, urban and transport planning, encroachments, land use control are vested to
Tehsil Municipal Administrations, therefore TMAs are the best appropriate level to study the level of governance. Hence current research aims at exploring the urban governance level at the second tier i.e. Tehsil Municipal Administrations in Punjab.

\section{Methodology}

Existing situation of Urban Governance in local governments of Punjab has been explored using UNHABITAT urban governance index (UGI). 100 percent sample size (144 TMAs) was taken to conduct the research. Data required as input in the index was both qualitative and quantitative in nature and collected through questionnaire survey as well as from secondary sources. Pertaining to more specific data such as city vision, customer satisfaction etc, survey was undertaken, whereas data regarding citizen charter, water supply connections was collected through 
telephonic questionnaire survey from concerned officials in respective municipalities/local govrnments. Whereas financial information, population statistics, data on local government elections and accountability related details was collected through published reports, laws and regulations. Data collected by virtue of type and source is given in Table 1.

Table 1. Data Collection by Type \& Source.

\begin{tabular}{|c|c|c|c|}
\hline S. No. & Data Name & Data Type & Source \\
\hline 1 & Population characteristics & Secondary & Population Census Department, Govt. of Pakistan \\
\hline 2 & $\begin{array}{l}\text { Local Government Revenue, Budget Details, Tax Details, Revenue } \\
\text { Transfer Predictability, Performance Delivery standards, Percentage of } \\
\text { Women in Key Positions }\end{array}$ & Secondary & $\begin{array}{l}\text { Local Government \& Community Development } \\
\text { Department (LG\&CD), Govt. of Punjab }\end{array}$ \\
\hline 3 & $\begin{array}{l}\text { Consumer satisfaction survey, Vision Statement, Citizen Charter, Water } \\
\text { Supply Connections, Civic Associations }\end{array}$ & Primary & Questionnaire Survey \\
\hline 4 & Percentage of Women Councillors, Incentives for Informal market & Secondary & Punjab Local Government Act 2001 \\
\hline 6 & Code of conducts, audit etc. & Secondary & Government laws., Rules and Regulations \\
\hline
\end{tabular}

The data was incorporated in the Index for calculation of output value using the following formulae:

Urban Governance Index = Average of (Effectiveness subindex + Equity sub-index + Participation sub-index + Accountability sub-index)

The final value ranges from zero to one. Zero indicates no governance whereas one represents very good governance. Furthermore data was also processed in Geographical Information Systems (GIS) to prepare map of the TMAs in Punjab so as to describe the level of urban Governance in graphical form. Finally, the TMAs were grouped and ranked on the basis of their respective scores/points attained as per primary and secondary data.

\section{Results \& Discussion}

\subsection{Effectiveness Sub Index}

TMAs in Punjab are performing not well in terms of effectiveness and have average Effectiveness Sub Index score as 0.32. In 2013-14 average per capita income of 144 TMAs was \$4.92 (Rs.492). Maximum revenue/capita was of Bahawalpur city and recorded as $\$ 82.52($ Rs.8252), whereas, TMA Karor Pacca had minimum revenue/capita of $\$ 0.23 \$$ (Rs.23). $63 \%$ of total TMAs had revenue per capita less than $\$ 4$ annually. Furtermore, the average ratio of actual recurrent and capita budget in 2013-14 was observed as 0.86 with minimum ratio observed in case of TMA DG Khan and Sahiwal whereas maximum ratio of 8.96 observed in case of TMA Yazman of District Bahawalpur. Similarly average ratio of actual tax collection to target/mandated tax was 0.98 with Minimum ratio of 0.3 observed in TMA Layyah whereas maximum ratio of 2.95 noted in Aroop Town of Gujranwala District. In addition to this more than $82 \%$ of TMAs collected $90 \%$ or more tax than their target.

On the other hand local governments in Punjab had high percentage of share of income from provincial government in the form of Provincial Finance Commission (PFC) award. The highest share of $78.5 \%$ observed in case of TMA Chobara of District Layyah followed by TMA Murree with share of $76.3 \%$. TMA Nandipur Town of Gujranwala district was found more financially independent with revenue transfer ratio as $3.1 \%$. As part of good urban governance indicator, every TMA had the knowledge at the start of financial year that what amount will be received from Provincial Government in the form of PFC share. However, contrary to the good governance, neither any TMA nor the Local Government \& Community Development (LG\&CD) Department published any performance delivery standards. Furthermore, neither customer satisfaction survey was carried out by any TMA for necessary feedback nor had any of the TMA formulated any vision for future development of its area.

\subsection{Equity Sub Index}

In terms of equity, position of TMAs was again quite poor with average equity sub index sore as 0.31 . None of the TMA had any charter documented for any of the mandated services. As per usual practice, TMAs exercised piece meal approach and focused on single problem rather to adopt a holistic approach. In addition, under the Punjab Local Government Ordinance 2001, 33\% seats are reserved for Women in Tehsil Council. However, these councils became nonfunctional after expiry of the tenure of local bodies in February 2010. Similarly, it was also observed that no women was working at any key position in $114(80 \%)$ of TMAs whereas in rest of $20 \%$ TMAs only $16.66 \%$ women were working on key positions. This situation shows inequity in terms of women participation in local governments in Punjab. It was observed that on an average $35 \%$ of households had access to municipal drinking water supply, however quality of water is still questionable. Some of the areas had less than $1 \%$ water supply connections due to the fact that in many area of Punjab, underground aquafers are present and all of the households are extracting water from underground through boreholes, thereby making the existing network of municipal water supply as uneconomic venture. As a result most of the urban water supply schemes are abandoned. However, in major urban areas WASA supplied municipal water to more than $90 \%$ of households.

Furthermore, certain mechanisms existed where TMAs would have charged less from poor settlements or specific group of people. For instance land use conversion fee was levied on the basis of plot area rather than flat rate in order to 
support the poor. However, in all TMAs uniform rate of water supply was applied irrespective of the socio-economic conditions of the area for the same land use. Moreover, all TMAs were providing equal opportunities for informal businesses to participate in the economic spheres of the society. For instance different bazars, markets were being managed by TMAs.

\subsection{Participation Sub Index}

Situation in terms of Participation was very poor with average Participation Sub Index score of 0.11 . This worse situation was attributed to the fact that no elected council was present at the time of survey since February 2010. It was because of the same reason that no locally elected mayor was present at the moment. However, according to Punjab Local Government Ordinance 2001, Mayor/Nazim is not directly elected but elected among the councilors. Furthermore, in upcoming elections of local government 2015, the chairman/mayor will also be indirectly elected amongst the councilors. Moreover, voter's turnout could not be accounted for in measuring the level of governance though in Punjab Local Government Elections 2005, average voter turnout was $47.86 \%$. Similarly, due to absence of elected councils, no participatory arrangements or alternative forms for community involvement such as public neighborhood committees, city consultations or people's assemblies were working. Furthermore, on an average 6-8 civic associations per TMA were working which indicated very less participation of formalized groups/organizations in decision making process.

\subsection{Accountability Sub Index}

Accountability sub index score was 0.97 which was very high as compared to the other sub-indexes. This high value was due to the fact that all TMAs in Punjab are bound by law to publish all tenders of value more than Rs.25000 (\$250) in at least two newspaper as well electronically printed media on PPRA (Punjab Procurement Regulatory Authority) website. Furthermore, all accounts and budget books are formally published at the start of financial year. These indicators depicted strong prevalence of accountability. Moreover, local governments are also accountable to provincial government under the Punjab Local Government Ordinance 2001, as well as the Punjab Local Government Act 2013. Provincial Governments may remove or take necessary action against any locally elected councilor on account of misconduct under the law. Similarly, all TMAs in Punjab have the authority to impose local tax, user surcharges, borrow funds and can award contracts for specific projects. Similarly, all TMA employees have to observe the code of conduct under the Punjab TMA Rules of Business, 2002. Besides, Punjab Employees Efficiency, Discipline and Accountability Act 2006 (PEEDA) is operative to take action any Govt. Employee for any negligence, inefficiency and misconduct etc. In addition, the elected representatives' code of conduct is also in vogue under the Punjab Local Government Ordinance 2001 as well as observed under the authority of Election Commission. Likewise, all the TMAs under Provincial Government directions have established Complaint cell and appointed specific personals for the purpose of transparency. However, the efficiency and output of these cells is question marked. No anti-corruption commission exists within the TMAs, however, the officers incharge at TMA level have been designated as accountability officers of respective departments. At the provincial level, anti-corruption establishment exists that is authorized to summon the cases regarding malpractices/corruption in the TMAs. Special judge Anticorruption is also appointed by the Province at divisional level to deal with such cases. Sound accountability is also attributed by the fact that all elected members and TMA employees are bound by law to disclose their income and assets annually for regular monitoring. Moreover, in all TMAs of Punjab independent Office under Tehsil Audit Officer are working to keep strict check and balance on financial affairs. Similarly, special audit is also observed by Inspection Teams at provincial and federal government level.

In addition to the indicator-wise analysis, the values of each indicator for 144 No. of TMAs were incorporated in the urban governance index formulae and results obtained. The average UGI score came up as 0.40 . Brief statistics of the results are shown in Table 2. Standard deviation observed during this process is calculated as 0.18 which shows that urban governance across all TMAs are close to each other.

Table 2. Brief Statistics of UGI of TMAs of Punjab.

\begin{tabular}{llllllll}
\hline & N & Range & Minimum & Maximum & Mean & Std. Deviation & Variance \\
\hline Effectiveness Sub Index & 144 & .33 & .15 & .48 & .32 & .04616 & .002 \\
Equity Sub Index & 144 & .25 & .20 & .45 & .31 & .04617 & .002 \\
Participation Sub Index & 144 & .11 & .00 & .11 & .02 & .02443 & .001 \\
Accountability Sub Index & 144 & .00 & .97 & .97 & .97 & .00000 & .000 \\
Total UGI & 144 & .11 & .35 & .46 & .40 & .01812 & .000 \\
\hline
\end{tabular}

Source: Field Survey, May 2015

The results also show that Nandi Pur Town of Gujranwala District have the highest UGI of 0.46 followed by Muree, Attock and Gulberg Town of Lahore District having UGI of
0.45. The lowest UGI was observed in TMAs of southern Punjab TMAs including Layyah and Karror Pacca with value of 0.35 (Figure 2). 


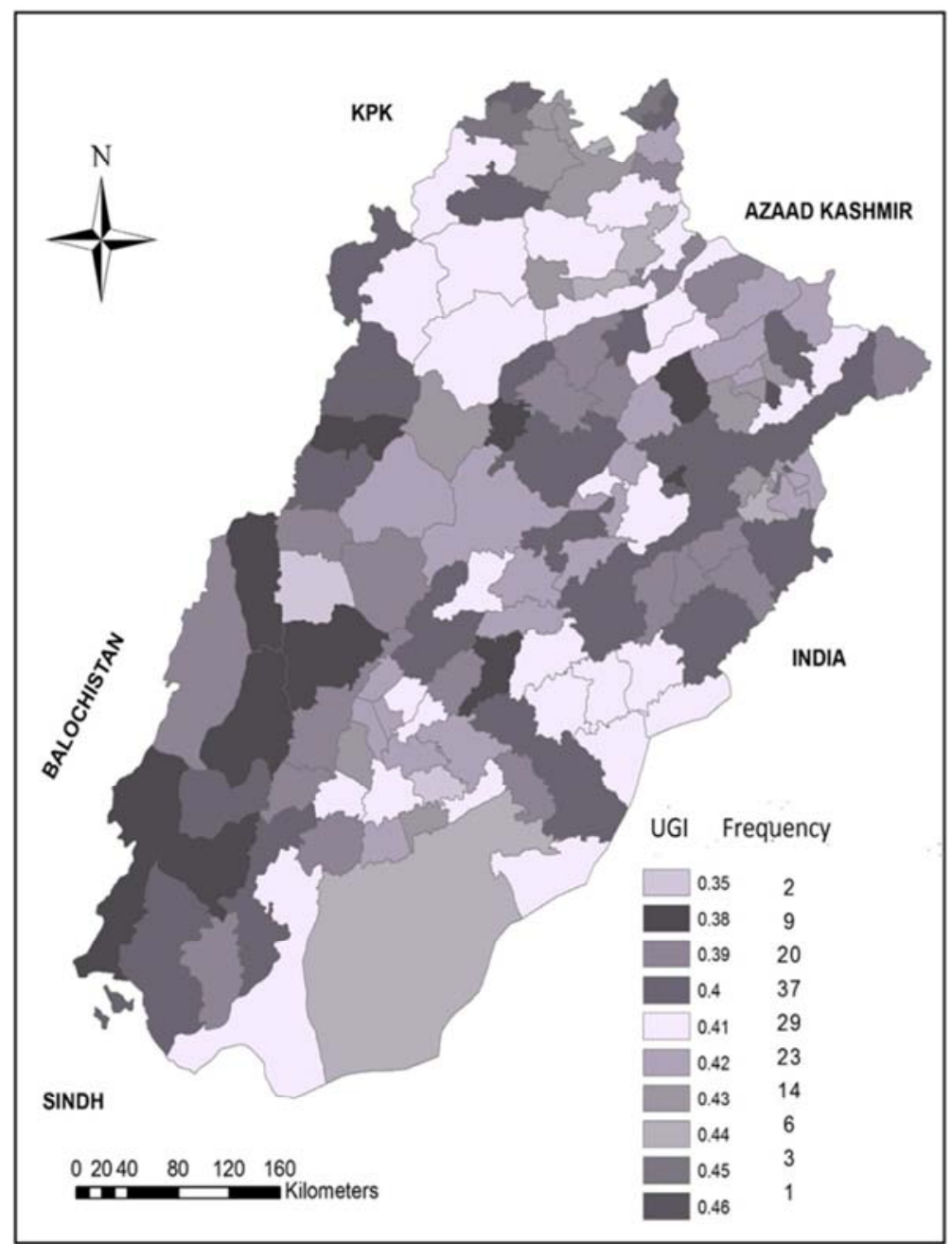

Figure 2. Urban Governance Index of TMAs of Punjab, Pakistan.

Moreover, it is also witnessed that level of governance decreased over the last 5 years due to the fact that participation sub index value was quite high prior to 2010 when elected local governments were intact. The participation sub index for year 2010 was recalculated using voter turnout percentage. Furthermore, Mayor/Nazim was selected by the elected mayors through vote count. Figure 3 depicts the picture of average UGI value prior to 2010 and in 2015.

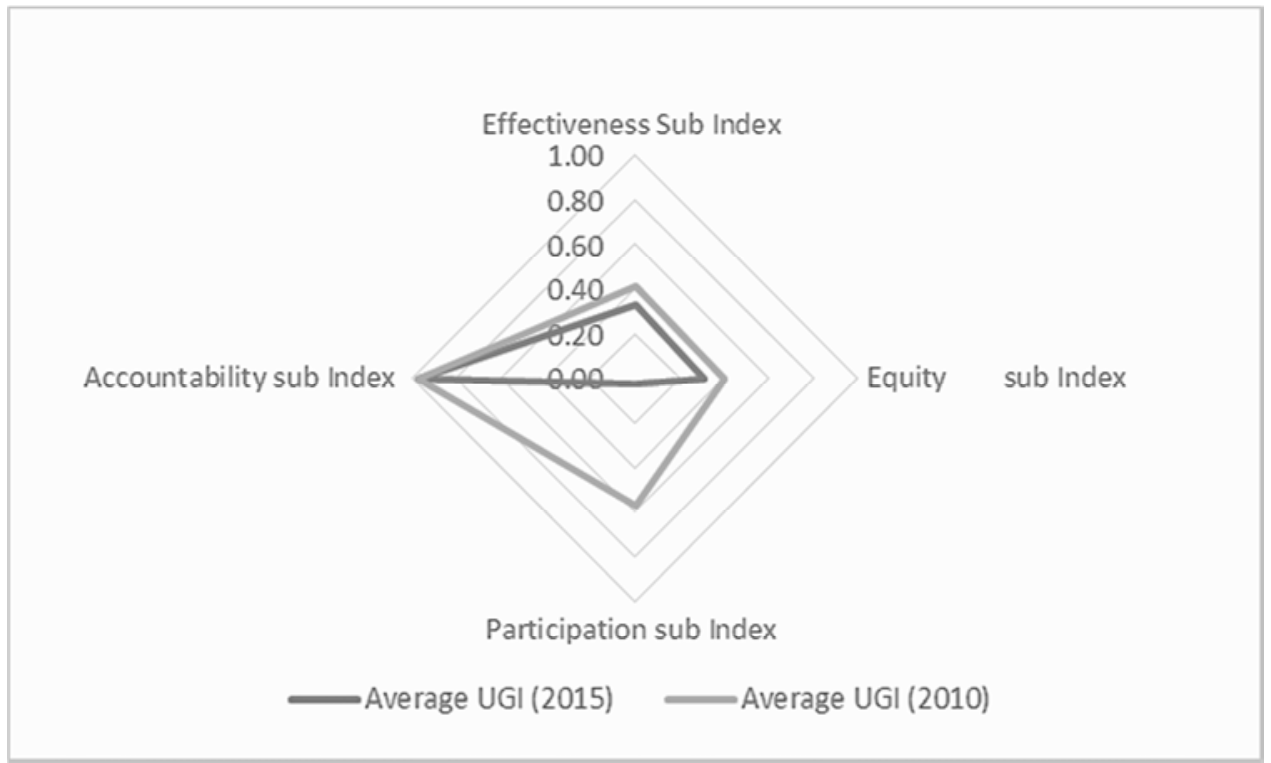

Figure 3. Comparing Average UGI in 2010 and 2015. 
In order to evaluate the level of urban governance it is necessary to compare the urban governance index of Punjab cities/TMAs with the rest of world cities. For this purpose results from field test of 22 different cities across the globe during the formulation of UGI by the UN HABITAT in 2004 were taken. In addition to this another study was conducted by UNDP in 2006 on the city of Ulaanbaatar, the capital of Mongolia and is used for comparison [19]. Similarly a study was also conducted by Zahid Sahfie titled "Contested Study of Urban Governance, A Case study of Tehran" in 2011 [20]. Detailed comparison of highest UGI of TMAs in Punjab with the rest of cities is shown in table. It can be seen that Attock which has the highest urban governance index of 0.45 within Punjab stands at 22 out of total 24 cities of developing countries of the world which clearly indicates the poor level of urban governance in Pakistan (Figure 4).

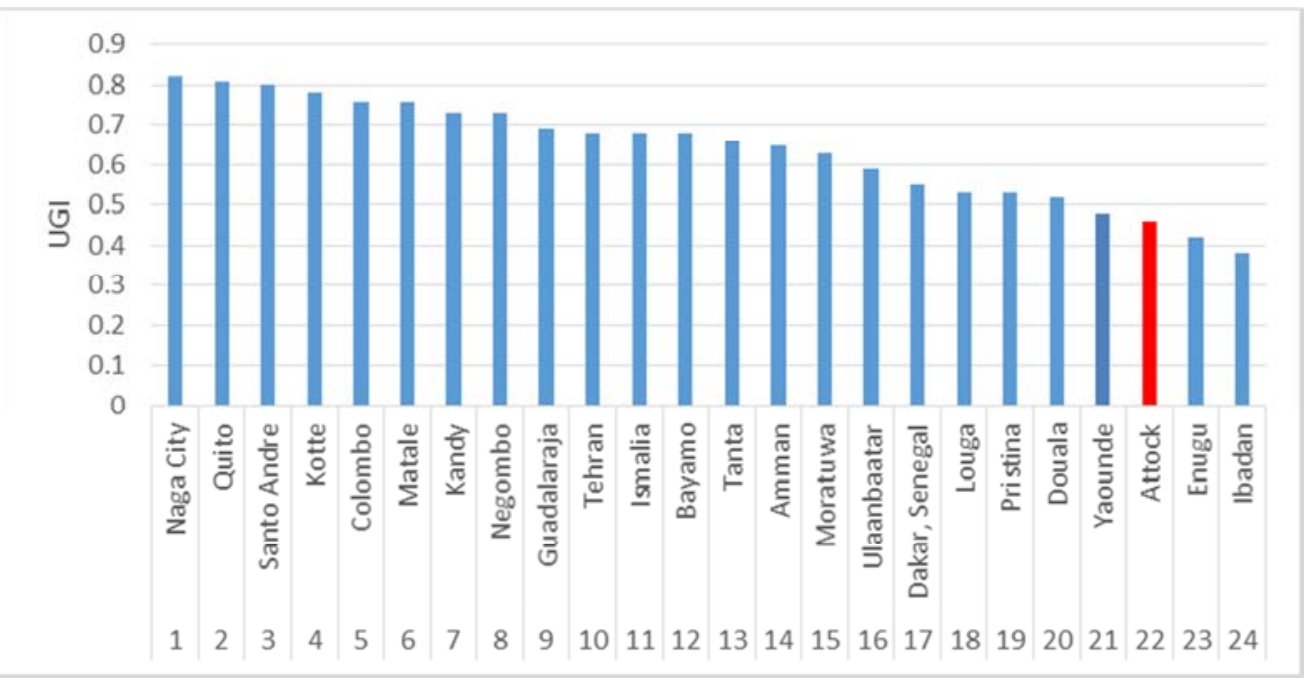

Figure 4. Comparison of UGI with cities of developing countries.

\section{Conclusion}

The preliminary results of application of UGI on local governments of Punjab (TMAs) have revealed that situation of urban governance is not good with score ranging from 0.35 to 0.36 . Participation sub index have the least score of 0.02 due to the fact that no elected government is present whereas accountability sub index value is 0.97 showing higher level of accountability in local governments. Moreover, accountability sub index value is constant throughout all TMAs since sub-index indicators and controlled and implemented by provincial government throughout all TMAs uniformly.

Results have also showed that on basis of cities, Attock and Muree have the highest UGI score of 0.45 whereas on the basis of TMA, Nandipur, a town of Gujranwala City District Government have attained the highest UGI score of 0.46. Whereas the least UGI value is observed in Layyah and Karor Pacca (0.35) and ranked on $10^{\text {th }}$ position in term of urban governance. Furthermore, it is also evident that among developing countries around the globe, Pakistani cities are at the lowest level of urban governance.

The low level of urban governance have also highlighted some challenges confronted by the TMAs across Punjab including low revenue generation, lack of public as well as women participation in city affairs, lack of financial autonomy, lack of vision, nonexistence of performance delivery standards and citizen charter for basic services, absence of elected local governments and poor service delivery. Therefore, it is direly needed to combat these challenges in order to enhance the existing level of urban governance in Punjab urban areas.

\section{References}

[1] UN, "World Urbanization Prospects-The 2014 Revision," United Nations, New York, 2014.

[2] D. C. G. F. David E. Bloom, "Urbanization and the Wealth of Nations," Science, pp. 772-775, 2008.

[3] FIG-Commission, "Rapid Urbanization and Mega Cities: The Need for Spatial Information Management," nternational Federation of Surveyors (FIG), Copenhagen, Denmark, 2010.

[4] J. Pierre, "Models of Urban Governance: The institutional dimension of Urban Politics," Urban Affairs Review, pp. 372396, 1999.

[5] U. HABITAT, "The Global Campaign on Urban Governance," Nairobi, Kenya, 2000.

[6] G. \&. D. S. McGranahan, "Governance and getting the private sector to provide better and sanitation services to the urban poor," Human Settlement Discussion paper series, Theme water-2, 2006.

[7] L. Moretto, "An application of th UN-HABITAT Urban Governance Index(UG): water supplies in a low-income community of the caracas Metropolitan Region," Habitat International, p. 435-444, 2015.

[8] UN, "Public Governance Indicators: A Literature Review," UN, New York, 2007. 
[9] K. Stewart, "Designing good urban governance indicators: The importance of citizen participation and its evaluation in Greater Vancouver," Cities, p. 196-204, 2006.

[10] F. L. a. M. M. Daniel Kaufmann, "Governance and the City: An Empirical Exploration into Global Determinants of Urban Performance," World Bank, 2004.

[11] U. HABITAT, "Urban Governance Index-Conceptual Foundation \& Field Test Report," UN HABITAT, 2004.

[12] W. Bank, "Managing Development-The Governance Dimension," Washington DC, 1994.

[13] S. Narang, "Disaggregating Governance Indicators: Why Local Governance is Important and How It Can Be Measured," New Delhi, 2005.

[14] U. HABITAT, "Global Campaingn on Urban Governance, Cocept Paper, 2nd Revised Edition," Nairobi, 2002a.
[15] World Bank, "Governance and Development," World Bank, Washington, DC, 1992.

[16] S. S. a. M. Ahmed, "Political and Administrative Structure of Local Bodies in Pakistan. A Case Study of City District Government Faisalabad," Berkeley Journal of Social Sciences, vol. 3, no. 6, 2013.

[17] Punjab-Government, Punjab Local Government Ordinance, 2001.

[18] LG\&CD Department, "Local Government in Punjab," Govt. of Punjab, 2001.

[19] F. E. Lange, "Urban Governance: An Essectial determiannt of city development?," World Vision Institute for Research and Developemnt, Germany, 2009.

[20] Z. Shafiei, "Contested Understanding of Urban Governance-A Case Study of Tehran, Iran," Phd Thesis, Newcastle University, 2011. 